Much work has been done during the last ten or twenty years on the mineral requirements of farm animals, and it is well that stock should be taken of our knowledge from time to time in an endeavour to obtain a true perspective of the progress which any advances provide.

This paper will be restricted to a discussion of the line requirements of sheep-.

Both to the research worker, and to those who are to-day interested in applying the results of research work, many questions will occur. They will ask "What progress has been made during the last fifty years concerning knowledge of the functions of lime in the animal body?" $T h$ h reply would be "Not very much." Or they mis ask "Just how much lime should a sheep receive in its food per day, per week or over the whole year?" One must answer "It is not known. Nobody knows," Or, finally, it may be asked "Will it ever be posaible to state' definitely the quantities which should be present in the food of the animal?" And to this the answer is "It is doubtful if tha answer will ever be known." Among those interested in the research side of nutritional problems tilere may be some who will disagree with these views, but .. - evidence will be produced to show that thereare grounds for the pessimistic line of thought suggested, Let us deal with the first question.

WHAT PROGRESS HAS BEFN MADE DURTNS THE EAST FIETY YEARS CONCERNING KNOWLEDGE OF THE FUNCTIONS OF LIME IN THE AITIAL BODY?

obtained In dealing, with any nutritional problem information ontgined species of animal is often just as applicable to an entirely different species, One is, therefore,- justified in discussing such problems from a wide angle, Many notable contributions have been made during recent years. regarding the part played by lime in the animal economy. Many of these advances have been made by the medical sciences working hand in hand with the chemist, the physiologist; the histologist, the dietidian, and with others, Their work has shown the important status of lime as an essential element of the body. But even to-day much of the knowledge is imperfect and incomplete, even in the minds of those whose researches have qualisied them to speak with authority. The remark of a leading medieal man writing on the use of calcium as a therapeutic agent sums up rather aptly the present position of knowledge in regard to She whole question of line in animal nutrition when he said "The present use of calcium is : in many instances? the introduction of an agent of which the physician knows little, into a body of which he knows less, in entire forgetfulness of the universal rule that any agent capable of doing good is capable, if improperly used, of doing harm." And so it is in regard 
to the nutritional requirements of farm animals. It is known that lime is necessary for bone formation, membrane permeability, heart action, the coagulation of blood and milk, nerve and muscle excitability, and the maintenance of the acid-base equilibrium in the blood, but the manner in which it acts in man of these cases, just how indispensible it is, and the optimum and minimum level:s are still exceedingly obscure. It is also known that... associated with certain diseases, or nutritional disorders, there may be an increase or a decrease in the level of the calcium in the blood and that cures of these complaints are associated with a retirn of the blood calcium to normal again but the mechanisms whereby these changes take place still await, in many cases, a solution.

One well known example is the case of milk fever in ewes and cows: It has been established that this is. invariably accompanied by a fall of the blood calcium from a normal value of about $10 \mathrm{mg}$ o per $100 \mathrm{c} \mathrm{c}_{2}$-of blood serum down to levels as low as $2 \mathrm{mg}$, per $100 \mathrm{coc}$. The records of 127 cases investigated at Canterbury Agricultural College last year were as follows:-

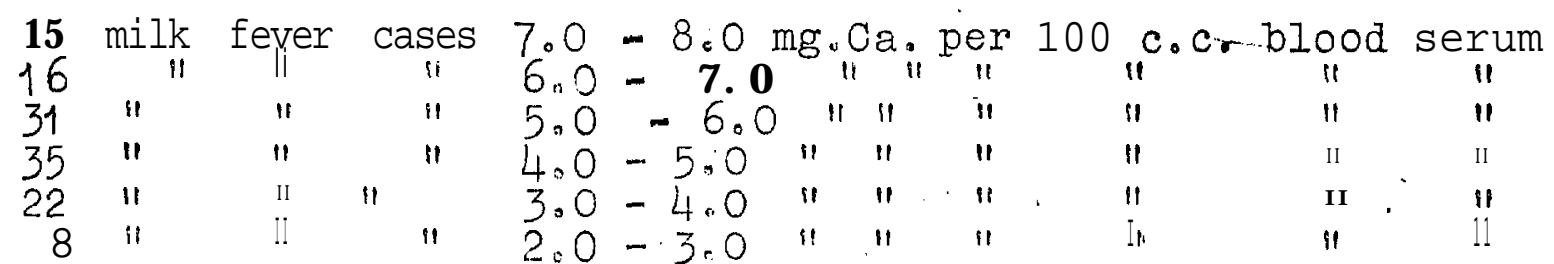

Many of the animals from which these samples were collected responded to udder inflation, while others did not. recover. Mr. A. Leslie (1934) of the Veterinary Department of Canterbury Agricultural College, who carried out the veterinary side of the work, has classified these milk fever cases into three-groups; -

(1) Poorly nourished ewes suddenly put on to a green diet and not started to form milk..

(2) Well fed and well nourished ewes (apparently high producers) and forming mi ik, and

(3) Poorly nourished ewes ccilmencing to form milk,

All types siowed a subnormal' blood calcium but knowledge of the level of the calcium in the blood does not offer a clear solution of the cause of the trouble, Milk fever has been called "The Disease of Theories." Numerous theories have been put forward since the timeving shidt, believing it to be of bacterial crigin, stumbled on the udder inflation 'method in 1897, or at least suggested a method of treatment which by a happy accident led to the adoption of the udder inflation method and by its vise reduced the mortality rate consider\&l?, And although to-day these various theories havebeer disproved or rejected the true etiology of the disease? still awaits solution, It can be stated fainly definitely that this decrease in the calcium in the blood is due to a dysfunctioning of certain of the glands of the endocrine system, e.g. the parathyridd glands, but whether other glands. are also concerned and just what are the mechanisms involved are not known. Determination of the blood calcium is invaluable as a diagnostic aid, but that St all that can be said for it. 
Following on the discovery by Little and Wright (1925) and Dryere and Grej.g (1925) in England that in milk fever cases there was a Iowering of the blood calcium there were many who suggested that this ajoagemat be associated with, or the result of, a deficienery hinge diet of such animals, but an examination of prectical and experimental data cannot support this clairn. cows, even on the richest of pasture, have been lnowntio suffer from an attack of milk fever. True, these are often the heaviest milkers, but, as Annett (1931) pointed out very oleariy at the meeting of the New Zealand Grassland Associetion in 1931 ; it. is very difficult to believe that on intensively managed pasture, they are not receiving sufficient lime in thein food to satisfy their requirements if digestive and other bodily functions are normal. Further, it has been shown that cows can produce for months on a diet which is supplying only a half, or even less than a half, of the lime that is boing removed daily in the milk. This is well illustrated or tine work of Groenewald (1935) at Onderstepoort who has published recently data for- cows kept on an exceptionaliy low lime diut for two lactation periods. Such a drain of minerals must, of course, be serious, but these and similar experiments emphasise the high powers of adaptibility possessed by the animal. in periods of shortage it can draw on its reserves, in periods of plenty these can be built up again. Under these conditions of lime imbalance milk fever need not occur, In fact it is doubtful if. it is much more frequent than when the diet is perfectly adequate. . as judged by our present day nutritional standardsfor stock, The same remarks must apyly to milk fever in ewes, except perhaps, in those cases mine information collected by Leslie suggests that a zow plone of mution can be a predisposing factor in the incidence of the divease. It would appear, therefore, that it will be necessary to look elsewhere than to the lime content of the diet for the true explanation of the cause of milk feroy in fam aninal.s.

If further proof is required for the justification of the views expressed'it is sunpijed by an experiment commenced nearly four years ago ivy the authon at Cambridge University. Several eres were piaced on a diet which was particulhrly low in lime and were rep on this carefully controlled diet consisting of hay and Pailed raize for $2 \frac{1}{4}$ Joars. They

ver:o receiving about $+.5 \mathrm{~g}$. of coo per day (a pasture containing 0.5 per cent of lime would have supplied to the ewes which averaged 1501 b jive weight, appoximateli 12.4 gn per day', a 700 per cent increase) ni yet none died with symoms identical with those usually associated with milk fever, some did die, but as a result of some other calses: $\theta .8$. in two cases from a pregnancy toxaemia, and in another case through death of twin lambs in utero shortly before lambing, Three were able to rear their lambs, The nuber of ewes worked with - nine was rather small to allow ver defint te conclusions to be

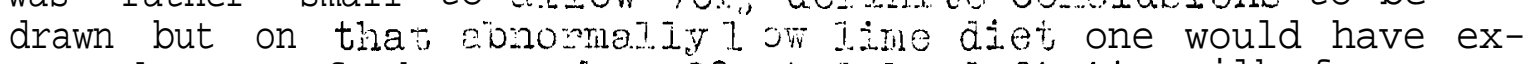
pected some of them to be afiected ou definite milk fever symotom: if milk iever can be the direct result of " I. :... a lime dericienoy in tile diet,

\section{MAIROA DISEASE,}

This experiment nad not beer undertaken with the sole purpose of intestigating the cause of milk fever in ewes. At that time Masroa dicease in New Zealand was considered by some to be due to a defichency of ine in the pasture. Aston (1 928) had found that the pastupe contained percentages of CaO as low as 0.59 per cent. On such vaswures, ewes averaging 
$1301 \mathrm{~b}$ would receive $10.8 \mathrm{~g}$ : of Cao per day, over six times as much as the animals used in the Cambridge experiments, so that it was felt that if a serious lime deficiency was the cause of the trouble which Aston credited to lack of lime, then these animals should probably suffer from it after several months on this deficient diet, As a result. of this rirk the author (Franklin 1933) expressed the following views regarding Mairoa disease when taking part in a discussion on mineral deficiency diseases at a meeting of the Royal Society of Medicine in London in 1933.

"In the case of Mairoa disease in New Zealand, Aston gives the amount of lime (Ca) in some of the poorest Mairoa pastures as 0.59 per cent, If a sheep consumed from $2 \frac{1}{2}$ to 31 of this pasture per day it would receive from $\mathbf{6 . 7}$

to 8.0 g. lime. I know areas where good healthy sheep are reared on pastures f-rom which they would derive a smaller daily intake of $\mathrm{CaO}$ than tinis, and I therefore find it difficult to believe that the trouble is due to the pasture being low in lime. Aston has, of course, shown conclusively that the Mairoa soil is lime deficient, and has stated that originallygafter forest burns some years ago, stock thrived there on the good tygo of pasture then present, but owing to the gradual leaching out of the soil nutrients with the heavy rainfall, the pasture has gradually reverted to an inferior type consisting of danthonia, fog, etc.

In view of this tould it notreasonable to assume that the cause of the trouble among sheep in the Mairoa district is not a lime defjeiency per se, but a lowered level of nutrition resulting in genera;. malnutrition?

In my work at Cambridge, eves which rere receiving only about $1.5 \mathrm{~g}$. CaO per aay for the last 18 months - and which during this period have had two pregnancies, are still norial in appearance, I Dolieve ths slipports my opinion that the main trouble in $11 a$ ion doninese $3 \mathrm{~s}$ due to- some other factor or factors, Topdresing with 5 cwt of lime and 2 cwt. of superphosphate per acre cures tile trouble,. but this, at theqmene, improves the quality of the pasiure; so that while a manuring experiment of this ature wil prevent the disease, it does not enable us to determine the cause."

All information obtajned since that time fails to justify a modification of these views. The different environmental conditions unden wich the Cambridge animals mere kept might be used as an argumentagainst the above conclusions, Here in Canterbury, however. sheep are peared, and reared successfully, on pastures which show as low, on even lover lime content than the analysis of the Mairoa pastures. If there are still some who consider that the troubie experienced with sheep 'in the Te Kuiti area is the direct result of a lime deficiency, the following information may be of interest to them.

The two classes of sheep wich will require the greatest quantity of lime in their Iocd will be the milking ewe and the voung growing lamb or koget. Woodman (1933) says that/fuckling lambs give $2 \frac{1}{2}$ to $3 \frac{1}{2}$ gallons of milk per week. The latter figure may be too hign ?or certain breeds but if it is taken as the maximum yield it is interesting to compare the lime output in this with the eve's lime intake from her food, During this time of the year tine owes will be consuming grass and here in Canterbury a reasonable estimate of the lime content should be an average of any November - March. At Canterbury Agricultural Coliege tins has been foun to equal 0.72 per cent. 


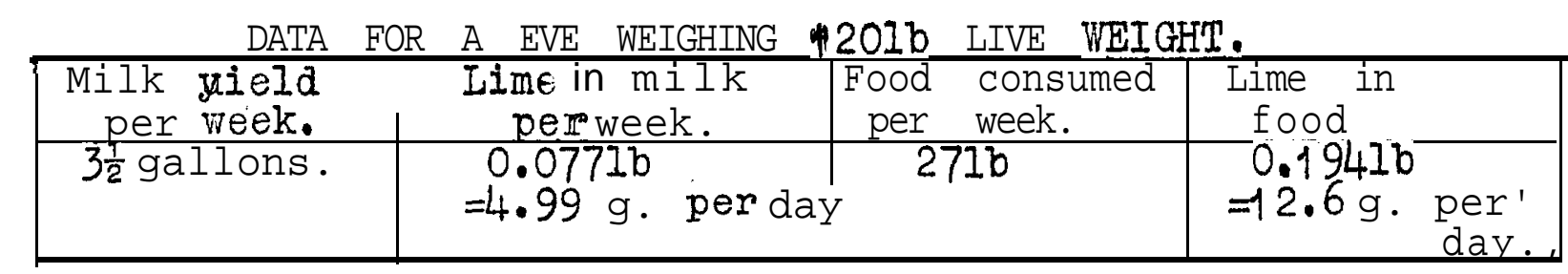

Even when due allowance is made for functions of I i me, other than milk requirements, and a low degree of utilisation it is adifficurt to reconcile such figures with any theory postulating a shortage of lime in the diet - and this is at a period of the year when the ewe would be expected to require maximum amounts.

Furthermore, a young lamb which has been reared under good conditions will be $70-801 \mathrm{~b}$ live weight at four months when it is weaned say in December or January. By the following January it would probably have increased its weight under Canterbury conditions to about 100 to $1201 \mathrm{~b}$, an increase of about 20 - 501b. Slaughter trials have shown that a sheep (fasted live weight) will contain in its-body, from $1.18-1.32$ per cent of lime according to its condition. Consequently the maximum storage of lime should not exceed $0.661 \mathrm{~b}$ during approximately 12 months O $\mathrm{I}^{\prime}$ an average of 0.0018 lb $(0.82$ g.) per day. Again it is difficult to believe that there could be, in our hew zealand pastures, insufficient lime to satisfy the above demands, under even the most diversified conditions.

In regard to various bone diseases considerable progress has been made. The etiology of rickets, ostemaniacia, osteoporosis and allied disorders have been investigated fairly compietely. In view of the fact that they are associated with a lack of disposition or excessive resorption of lime (and phosrhate) salts from the body they may be mentioned-but it is scarcely within the'province of this paper to deal with them in any detail.

Vitamin D should, perhaps, also be mentioned since it plays such an important part in the metabolism of calcium in the body. The complete elucidation of the manner whereby it acts still awaits solution.

Sufficient has been said, however, to show that in regard to the first question raised earlier in the paper, Iame:Iy "What progress has been made during the last fifty years concerning knowledge. of the functions of lime in the body" many; difficult points await solution.

to be made.

Much progress has been made; much more requires

WHAT ARE THE DAILY LIME REOUIREMENTS IN THE FEED OF ASHEEP?

You will notice the question is "ir the feed." A fairly accurate estimate can be made, of course, o: the appr:ximate amounts of lime required to be stored the animal.. at various stages of growth. Using data whicil Henry and Morrison (1928) quote from slaughter experiments the following table of lime storage could be constructed to represent maximum storage rates' for lime - 
and thenthe case of pregnant eaes further additions could be made for the. developing lamb. This would be found to increase with the age if the foetal lamb. Bass (1923) gives the following figures as the absorption of calcium by the foetus in the human being:-

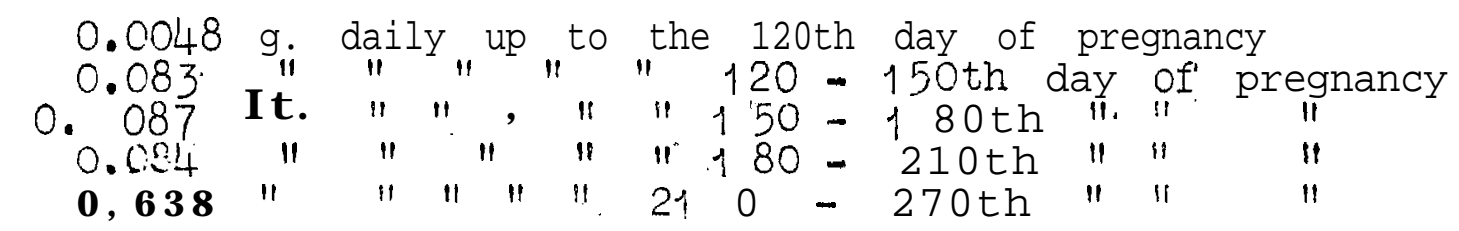

A somewhat similar relationship should hold for ewes, the foetal demand for lime increasing as bone formation became fairly rapid during the latter months of the gestation period.

And finally the quantity of lime in the milk can be 'calculated with a fair degree of accuracy. Sufficient work has been carried out to give an approximate idea of how much milk is secreted by a eve while suckling her lamb. The percentage of lime in this remains fairly uniform under the most diverse conditions so that the average daily or weekly output in the milk can be calculated. Pröscher (1914) found that ewe's milk contains 0.271 per cent CaO, Abderhalden (1914) 0.245 per cent, Shearer and Stewart (1931) in a comparison of the milk of ewes on poor hill pasture in Northumberiand with that of a similar mob receiving a mineral supplement obtained 0.215 per cent and 0.224 per cent respectively. The lime deficient ewes at Cambridge yielded milk varying from $0,200-0.299$ per cent of GaO.

All this data will give the total quantities of lime which must be removed from the diet of the animal (excluding that excreted in the urine - a very small amount; and that excreted through the large intestine into the faeces and voided with it - a varying amount which may be quite large at times) but is no index of the amount which must be present in the food. It would be necessary to know the digestibility or availability of the lime in the food in order to determine this. It would probably be possible to find this out with a reasonable degree of accuracy if rations were absolutely standardised, if the percentage of fibre was alvays the same, if the lignification had proceeded to the same degree, if mineral ratics: did not vary, hnd so on. Such, however, is not the case in practice and can never hope to be, so that it is not necessary to follow such a train of thought further.

One does not have to work for any length of time on mineral metabolism studies in order to find vastly different storage rates under a level of food intuke which remains fairly constant.It is evident that thereinust be a multiplicity of factors which will account for thi\$." This is amply borne out by the following storage rates df: some of the animals experimented vith at Cambridge. 
(7)

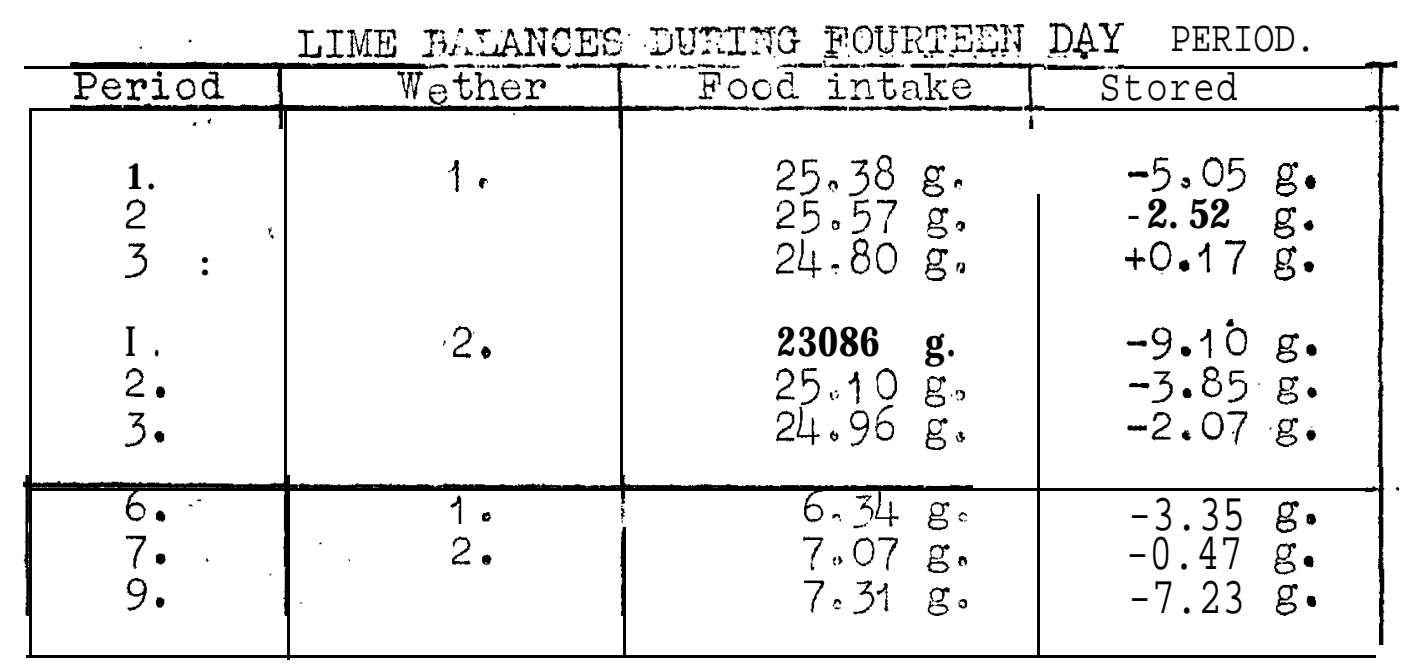

It is sometimes possible to explain differences such as those shown by the two animals in the above tableg, but more frequently a correct inteopretation of the data is not possible, The large fluctiations in the fortnightly balances with the above animals were undoubtedly due partyy to the fact that they. were on an abnormally low diet.

In some experiments that were carried out a-k Canterbury Agricultural College iast year with mature wethers which were receiving a much larger food intake of lime, these discrepancies were still-observed.

\begin{tabular}{|c|c|c|c|}
\hline Period & Wether & Food intake & Stored \\
\hline 1. & $\begin{array}{r}23 \\
348 \\
468 \\
48\end{array}$ & $\begin{array}{l}129.8 . \mathrm{g} . \\
127.4 . \mathrm{g} . \\
148.5 \mathrm{~g} . \\
148.5 \mathrm{~g}\end{array}$ & $\begin{array}{l}+15.5 \mathrm{~g} \\
+4.9 \mathrm{~g} \\
+22.0 \mathrm{~g} \\
+16.1 \mathrm{~g}\end{array}$ \\
\hline 2. & $\begin{array}{r}23 \\
348 \\
468 \\
48\end{array}$ & $\begin{array}{l}145.28 \\
114.8 \mathrm{~g} . \\
152.4 \mathrm{~g} . \\
168 \mathrm{~g} .\end{array}$ & $\begin{array}{l}-2.5 \mathrm{~g} . \\
-4.0 \mathrm{~g} . \\
-2.8 \mathrm{~g} \\
+3.0 \mathrm{~g}\end{array}$ \\
\hline
\end{tabular}

WIIL IT EVER BE POSSIBLE TO STATE DEFINITELY THE QUANTITIES WHICH SHOULD BE PRESENT IN THE FOOD OF THE ANIMAL?

Such factors as the availability of the minerals in different types of feed, the effect of alteration of the mineral ratios, variations in the vitamin $D$ eontent of the food and other factors influencing absorption in the alimentary canal, the change in the requirement of the animal at different times of the year, and variations which are the result of certain idiosyncracies peculiar to individual animals must preclude the hope that our knowledge of the subject can ever be a very exact one.

It is only necessary to consider the data given by different authorities for the requirement of farm animals in order to realise their trabilify to agree, on definite standard values. Take for example the milking cow. Based on Kellner's standard, namely $32.5 \mathrm{~g}$. Ca per $10001 \mathrm{~b}$. te weight and $0.87 \mathrm{~g}$. $\mathrm{Ca}$ per $\mathrm{lb}$. of milk, the requirements per gallon of milk are:Maintenance, plus 1 gaizion 41.2 g. Cia.

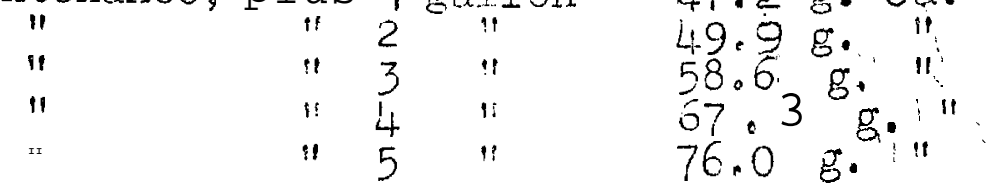


(8)

These figures of Kellner imply a utilisation of 62 per cent of the food calcium for milk formation.

Crichtcn (1930), however, says that on an ordinary ration an assimilation of 15 to 20 per cent of the mineral matter may be expected. Assuming that only 20 per cent of the food calcium is assimilated, then the requirements for a $10001 \mathrm{~b}$. cow would be:-

$\begin{array}{cccc}\text { Maintenance, plus } & 1 & \text { gallon } \\ \text { II } & \text { " } & 2 & \text { "1 } \\ \text { II } & \text { " } & 3 & 11 \\ \text { II } & \text { " } & 4 & 11\end{array}$

$\begin{array}{rrrr}59.4 & \text { g. } & \text { Ca. } & \\ 8603 & \text { go } & & \\ 113.2 & \text { g. } & \text { " } \\ 140.1 & 5^{2} \cdot \quad & \\ 167.0 & \text { g. } & \end{array}$

Kellner's figures are considerably lower than those given by Crichton which emphasizes the uncertainty of our knowledge of the mineral requirements for 'such a well known substance as lime and in view of the wide range in the quality of the grass, hay, ensilage, and various supplementary crops other than grass such differences as those in the above table will always be encountered.

Another factor which must be remembered in any attempt to draw up definite dietary standards is the remarkable degree of adaptibility possessed by animals. The experimental sheep used at Cambridge showed this to a marked degree. Young growing wethers placed on the same low Iimo diet as the twes which have already been mentioned were subject\&\&O metabolism studies, Although their food intake was well below the usually accepted dietary standards they soon adjusted their lime balances and even managed to store a small amount. A further reduction in the lime in the food supply once more threw the animals on to a negative lime balance, but this was again adjasted by the animals to a positive cne. This will be clear from the data in the following table.

' LIME BALANCES.

\begin{tabular}{|c|c|c|c|c|c|}
\hline \multicolumn{3}{|c|}{ Lamb No. 1} & \multicolumn{3}{|c|}{ Lamh No. 2} \\
\hline Period & $\begin{array}{c}\text { Daily Food } \\
\text { Supply }\end{array}$ & $\begin{array}{c}\text { Mean Daily } \\
\text { BaIance }\end{array}$ & Period & $\begin{array}{l}\text { Daily Focd } \\
\text { Supply }\end{array}$ & $\begin{array}{l}\text { Mean Daily } \\
\text { BaIance }\end{array}$ \\
\hline $\begin{array}{l}1, \\
2 . \\
3 .\end{array}$ & $\begin{array}{l}1.81 \mathrm{~g} \\
1.82 \mathrm{~g} \\
1.77 \mathrm{~g} .\end{array}$ & $\begin{array}{l}-0.36 \mathrm{~g} \\
-0.18 \mathrm{~g} \\
+0.01 \mathrm{~g} .\end{array}$ & $\begin{array}{l}1 . \\
2 . \\
3 .\end{array}$ & $\begin{array}{l}1.70 \\
1.79 \\
1.78\end{array}$ & $\begin{array}{l}-0.65 \\
-0.27 \\
-0.15\end{array}$ \\
\hline $\begin{array}{l}4 . \\
5 .\end{array}$ & $\begin{array}{l}1.29 \mathrm{~g} . \\
1.05 \mathrm{~g} .\end{array}$ & $\begin{array}{l}-0.03 \mathrm{~g} . \\
+0.09 \mathrm{~g} .\end{array}$ & $\frac{4}{5}$ & $\begin{array}{l}1.10 \\
1.30\end{array}$ & $\begin{array}{l}-0.21 \\
+0.05\end{array}$ \\
\hline 6. & $0.45 \mathrm{~g}$. & $-0,24 \mathrm{~g}$. & 6. & .0 .34 & -0.35 \\
\hline & Iamb No. & & & $\operatorname{Lamb} \mathrm{NO} \cdot 4$ & \\
\hline $\begin{array}{l}1 . \\
2 . \\
3 . \\
4 .\end{array}$ & $\begin{array}{l}0.71 \mathrm{~g} \cdot \\
0.67 \mathrm{~g} . \\
0.97 \mathrm{~g} \\
0.77 \mathrm{~g} .\end{array}$ & $\begin{array}{l}-0.24 \mathrm{~g} . \\
-0.14 \mathrm{~g} . \\
-0.18 \mathrm{~g} . \\
+0.12 \mathrm{~g} .\end{array}$ & $\begin{array}{l}1 . \\
2 . \\
3 . \\
4 .\end{array}$ & $\begin{array}{ll}1.21 & \mathrm{~g} \cdot \\
1.15 \mathrm{~g} . \\
1.27 \mathrm{~g} . \\
1.17 \mathrm{~g} .\end{array}$ & $\begin{array}{l}-0.24 \mathrm{~g} \\
-0.25 \mathrm{~g} \\
-0.08 \mathrm{~g} \\
+0.04 \mathrm{~g}\end{array}$ \\
\hline
\end{tabular}

It should be obvious, therefore; that it is difficult, if not impossible to make any statement regarding definite requirements for farm animals,

\section{THE APPROXIMATE ASSESSMENT OF LIME REEUIREMENTS.}

If the above statements and assumptions are correct the question naturally arises - "What standards should be adopted for farm animals?" 
It has been made adequately clear that this will not be a fixed amount - milking ewes will require more than dry sheep; young growing lambs more than mature ones, and so on, In practice possibly the rafest recommendation that could be made would be to calculate the amount stored in the body, or utilised in milk formation, etc. and assume a 30 60 per cent utilisation of the lime in the food and then calculate. the quantity which would require to be present in the food to satisfy this demand, The percentage utilisation (30 - 60 per cent) will depend upon such factors as (1) nature cf foodstuff, e.g: young grass is much more digestible than more mature material, (2) nature for which required, e.g. the data obtained by various research workers suggests that lactating animals utilise the minerals in their food more efficiently than ron-lactating animals.

Despite the large volume of information which is available on the lime requirements of farm animals, the mass of experimental material which has been collected by the different Research Institutions, and a certain amount of theorising on the subject, it is not possible yet to aran tip a definite set of feed requirements for sheep under various dietary conditions., The wiew has been taken in this paper that this will no", be possible and reasons for this have been $\mathrm{g} i \mathrm{v} e \mathrm{n}$,

Under those conditions where supplementary feeding is practiced fairly extensively, the shortage of lime in certrin feeds may, of course, become serious and the addition of Iilie supplements may not only be advisable, but may even be necessary if success is to be achieved. The remarks in thia paper, however, are written more from a grassland point of view for those localities where the major 'portion of the animals' requirements are derived throughout the year from grass. The subject of supplementary feeding rnould increase the scope of this paper too much and it is not proposed to. deal with it here,

A fruitific line of investigation would be to extend mineral investigations to our poorer country - our brown-top and danthonia postures and tussock country. Fairly detailed information is available concerning the mineral content of good pastures on medium and heavy land, the effect on them of rainfall, seasonal changes and the infiuence of fertilisers, but these are not the areas where supplements of lime and phosphate will be necessary, Concerning: those areas in New Zealand where licks may be necessary, a consicierable paucity of information axists.

Instead of treating this question of the lime requirements of sheep in the way that has been done in thin paper various positive experiments which have been carried out could have been discussed or the author"s Cambridge experiments could have been dealt with in more detail.

The somewhat pessimistic line of thought adopted has been prompted by many frequently a sking. if mineral supplements should be fed to sheep,. Often the sheep are doing well withoug them, the lambing percentages are good, and very little trouble of any kind is being experier.ced with the flock. 
No doubt many of you here have been asked the same question and perhaps your answer has been framed, not so much by the dictates of your conscience, as by the generally accepted view. And the answer will, no doubt, have been in the affirmative, inpractically every case, while at the same time mental reservation may have been made that if it cannot-do them any good, it certainly will do them no harm.

But is this attitude good enough? It is true that in some dases the addition of lime may be beneficial and may add that elusive factor called "bloom" to the condition of your stock, but even more frequently no benefit may result.

The question naturally arises how can a true solution - $f$ the problem be arrived at? The laboratory side of experiments on lime requireinants is not being condemned in this paper - it has yielded, and will continue to yield much valuable information, but it will not be possible to give definite advie on the subject until large scale practical experiments are carried out, In the case of sheep reasonably sized

flocks would need to be studied side by side - one with the extra addition of lime, one without, Analyso of pasture would. need to be known. Possibly metabolism trials under the different sets of conditibns carried out on a fen animals would yield useful information and live weights of all the animals, wool growth, fertility, behaviour of their progeny, and various other factors would need to be studied. The scheme is perhaps Utopian, certainly it is expensive, hut the information wnuld be reliable and could be applied in practice.

In conclusion let it be clearly understood that this paper is not an attempt to belittle the work which has been carried out so far un the mineral requirements of sheep, or on the mineral content of their pasture and other feed under all conditions. Such information is invaluable even if it servos only to illustrate the limitations of our knowledge. It would appear, however, that the mineral side has been overemphasised in certain cases. The feed intake may be insufficient to satisfy the demands of the animpl at Certain Stages in its life, for example the poorer types of pasture during the huight of lactation, but the drain of lime from the bone reserves at this time can, under average, 'conditions be built up again during the non-lactating and ron-pregnant period. In this paper an endeavour has been made to present a truer perspective of the position in regard to eertain aspects of the lime requirements of sheep. It has, of course, been possible to deal with only a few of the major points which discussion of such a subject should suggest.

\section{REFERENCES.}

Abderhalden (1914) Quoted by Forbes and Keitb $\left(1,91_{1}, 4\right)$ Pröscher $\}$ Ohio Agric. Expt. Stat. 'Pech. Bult. No. 5. 159. Annett (1931) Rept. First Culfer. N.Z.Grassland Asscn. 24 . Aston (1928) N.Z. Journal of Agriculture, 37., 145.". Bass (1423) Quoted by Widdows (1923) Biocnern Journal $17,34$. $\begin{array}{llll}\text { Crichton (1930) J.Dairy Res., } & 1 \\ \text { Dryerre and Greig (1925) Vet.Rëc., } 5,225\end{array}$

Franklin (1933) Proc. Roy. Soc, Med. 26, 983. Groenewald (1935) Onderstepoort Jn 14 is. Henry and Morrison (1 928) "Feeds añd Feeding,"17. weslie (1934) Half-yearly Rept. Canteibury Agric. Coliege. Sep.14
Little and wight (1925) t.Brit.tJ. Exp. Path. 6, 129. Shearer and Stewart (1931) Univ. Camb Ins Animal Path, 2nd Woodman (1933) "Rations for Livestock" Bu11.48. Ministry of Agriculture and Fisheries. 35. 